\title{
Customer Satisfaction in Inbound Call Centers: A Study on the Role of Responsiveness and Assurance in Perceived Service Quality
}

\author{
Dr. Krishna Mohan Vaddadi ${ }^{1}$, Fatih $\mathrm{Cura}^{2}$, Navulur Krishna Surarchith ${ }^{3}$ \\ ${ }^{1}$ Dr. Krishna Mohan Vaddadi, Dept of Commerce \& Management Studies, Andhra University, India \\ ${ }^{2}$ FatihCura, Faculty of Administrative Sciences and Economics, Ishik University, Iraq \\ ${ }^{3}$ Navulur Krishna Surarchith, Faculty of Administrative Sciences and Economics, Ishik University, Iraq (Research Scholar of \\ Dr. B.R. Ambedkar University, India)
}

\begin{abstract}
The aim of this study is to analyze customer satisfaction in Inbound Call Centers and examine the relationship between Responsiveness and Assurance in Perceived Service Quality. The researchers proposed to study theoretical foundations on customer satisfaction and service quality dimensions adopting SERVQUAL Model to investigative the impact of service quality dimensions on customer satisfaction to meet the research objective. The association between perceived service quality and customer satisfaction will assist call center management to clarify the role of service quality dimensions in perceived service quality through customer point of view. The respondents for this study are the customers who receive service from call center of Telecommunication service providers in Visakhapatnam, Andhra Pradesh, India.

This research tested the effect of service quality dimensions on customer satisfaction and reported that both dimensions (responsiveness and assurance) had positive impact on customer satisfaction. Research results explore that Assurance has more impact on customer satisfaction than Responsiveness.
\end{abstract}

Keywords- Perceived Service quality dimensions, customer satisfaction, call-center, Vishakhapatnam.

\section{INTRODUCTION}

Customers are communicated by companies through call centers and contact centers which is customary means to render service. Customer Service Representatives (CSR) is used to serve specific services where human presence is required and Interactive Voice response (IVR) is used for generalized or frequently asked queries where predetermined set of questions and answers are prepared with an automatic voice where customers are given instructions to use the system. In bound call center is where customers contact the companies to get the service whereas out bound call center is where companies contact the customers to provide the service. Researchers chose in- bound call center for this study into consideration for analysis and respondents as customers who receive service from telecom service providers in Visakhapatnam, Andhra Pradesh, India. There are 4 major telecom service providers in Andhra Pradesh which are BSNL, Bharti, TATA and Reliance according to the report released by Telecom Regulatory Authority of India (TRAI) in 2014. (Bhawan, 2014)

The Customer loyalty and customer satisfaction are focus points of an organization. Retention of customers makes customers to re-purchase products that lead to loyalty towards organization which increases profitability (Zineldin , 2006). The price is not a concern for customers who get the satisfaction after buying a product or receiving service and becomes referrers of company's services and products to others. (Homburg,Koschate, \& Hoyer, 2005). The feedback of customers is based on acquiring satisfaction on product consumption which relies on organization's decision to render quality of service where quality level is directly proportional to customer satisfaction.(Kotler\& Keller, 2009, p.169). Quality became competitive tool for market share growth and materialization of contemporary markets where as traditionally it was treated as defensive instrument to protect interest of the customers (Davis, et al, 2003). The definition of service quality explains as the total evaluation on service rendered by the companies to customers where as many researches define as the degree of meeting expectations and needs of the customers in terms of providing service (Eshghi, et al., 2008). The literature survey reveals that perceived service quality dimensions are tangibles, responsiveness, reliability, empathy and assurance however the present research chose only responsiveness and assurance to determine perceived service quality and its effect customer satisfaction. 


\section{LITERATURE REVIEW}

Service was defined as 'any intangible act or performance that one party offers to another that does not result in the ownership of anything". It is also observed that service is an offer by one party to another party which is intangible with an intention to exchange money for contentment. Service quality is the expectation on products and services by customers. (Kotler\& Keller, 2009) Customer satisfaction is the expectation of the customer who purchases product from the company where he/she has beliefs before trying which turns in to reference or compare or judge the standardized product with product that is presented to him (Dietz et al, 2004). When product or service achieves better than the expectation of the customers, then it is positive disconfirmation, when it achieves lower than the expectation of the customers, then it is negative disconfirmation and when it achieves exactly equal to the expectation of customers, then it is neutral satisfaction or zero confirmation or disconfirmation (Oliver, 1997).

Most of the companies are using call centers for acquiring new customers and retaining existing customers which plays important role in serving as company's image. It is observed that the capacity of call center to produce considerable increased revenues by improved service which enables the sales opportunities which are prospective with an increased rapid growth.(Eichfeld, et al., 2006) It was proved in a study made by McKinsey that $25 \%$ of revenue got produced more through inbound call centers that were being run by credit card companies.

Responsiveness is the will of the companies to assist customers and render service promptly. Responsiveness is related to dealing of requests, complaints and questions from customers in a prompt and attentive manner. A firm's responsiveness is measured by the time it takes to communicate the solutions of the customers' problems. Customer's point of view is considered to achieve success by any company than company's point of view (Zeithmal et al., 2006.)

Responsiveness consists of recognition of customers' wants and needs, operational hours that are feasible to customer, personal concentration to each customer by the employees, priority to problems of the customers and transactions of customers to be dealt safely (Kumar, et al., 2009). Assurance indicates comfort inside the company area where customer enters, politeness and friendship that employees provide to customers, rendering advice with regards to finance related matters, experience and knowledge of staff and management, and simplicity in accessing information that is related to account by customers (Sadek et al, 2010,.)
III. CONCEPTUAL FRAMEWORK: RESEARCH MODEL

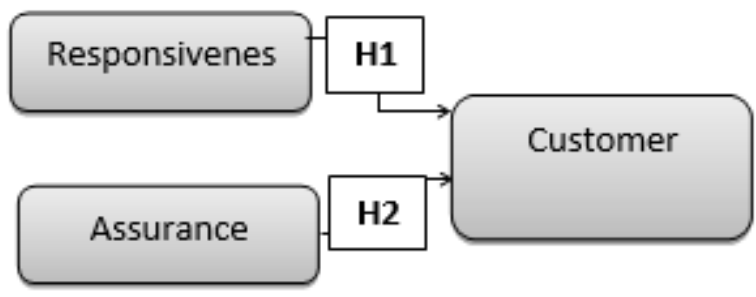

\section{RESEARCH HYPOTHESIS}

H1: There is a positive relationship between responsiveness and customer satisfaction in call center.

H2: There is a positive relationship between assurance and customer satisfaction in call center.

\section{METHODOLOGY}

The researchers used empirical quantitative research method to find out the relationship firstly between responsiveness and customer satisfaction in call centers and secondly the relationship between assurance and customer satisfaction in call centers. A questionnaire distributed among customers who received service from call centers that provide telecom services in Visakhapatnam, A.P., India. SPSS software was used for the purpose of analysis. The questionnaire was adapted from (Parusaraman, et al 1985). The researchers used random sampling method to cover the entire research population. The researchers distributed 80 questionnaires where 75 questionnaires were received and 68 questionnaires were completed properly.

Date Analysis:

Table.1: Reliability analysis

\begin{tabular}{|c|c|c|}
\hline Factor & $\begin{array}{c}\text { Cronbach's } \\
\text { Alpha }\end{array}$ & N of Items \\
\hline Responsiveness & .815 & 8 \\
\hline Assurance & .792 & 8 \\
\hline $\begin{array}{c}\text { Customer } \\
\text { satisfaction }\end{array}$ & .778 & 8 \\
\hline
\end{tabular}

As seen in table (1) the reliability test for all independent and dependent factors. The researcher found out the Cronbach's Alpha for responsiveness as independent factor $=.815$ for eight items, since $.815>.6$ this indicates all eight items used for responsiveness were reliable for this study. The Cronbach's Alpha for assurance as independent factor $=.792$ for eight items, since $.792>.6$ this indicates all eight items used for assurance were reliable for this study and finally, the Cronbach's Alpha for customer satisfaction as dependent factor $=.778$ for eight items, since $.778>.6$ this 
indicates all eight items used for customer satisfaction were reliable for this study.

Testing first research hypothesis:

Table.2: Correlation Analysis

\begin{tabular}{|c|c|c|c|}
\hline \multicolumn{4}{|c|}{ Correlations } \\
\hline Items & $\begin{array}{l}\text { Pearson } \\
\text { Correlation }\end{array}$ & $\begin{array}{l}\text { Responsi } \\
\text { ve } \\
\text { ness }\end{array}$ & $\begin{array}{l}\text { Customer } \\
\text { satisfactio } \\
n\end{array}$ \\
\hline \multirow[t]{3}{*}{$\begin{array}{l}\text { Responsive } \\
\text { ness }\end{array}$} & $\begin{array}{l}\text { Pearson } \\
\text { Correlation }\end{array}$ & 1 & $.669^{* *}$ \\
\hline & $\begin{array}{l}\text { Sig. (2- } \\
\text { tailed) }\end{array}$ & & .000 \\
\hline & $\mathrm{N}$ & 68 & 68 \\
\hline \multirow[t]{3}{*}{$\begin{array}{l}\text { Customer } \\
\text { satisfaction }\end{array}$} & $\begin{array}{l}\text { Pearson } \\
\text { Correlation }\end{array}$ & $.669^{* *}$ & 1 \\
\hline & $\begin{array}{l}\text { Sig. }(2- \\
\text { tailed) }\end{array}$ & .000 & \\
\hline & $\mathrm{N}$ & 68 & 68 \\
\hline
\end{tabular}

As seen in table (2) the correlation analysis between responsiveness as independent factor and customer satisfaction as dependent factor. The researcher found that the Pearson correlation for responsiveness $=.669^{* *}$ $\left(.669^{* *}>0.01\right)$ which indicates that there is a positive correlation between responsiveness as independent factor and customer satisfaction as dependent factor.

Table.3: Model Summary

\begin{tabular}{|c|c|c|c|c|}
\hline \multicolumn{5}{|c|}{ Model Summary } \\
\hline $\begin{array}{l}\text { Mode } \\
\text { Mode }\end{array}$ & $\mathrm{R}$ & R Square & $\begin{array}{c}\text { Adjuste } \\
\mathrm{d} \\
\mathrm{R} \\
\text { Square }\end{array}$ & $\begin{array}{c}\text { Std. Error of } \\
\text { the Estimate }\end{array}$ \\
\hline 1 & $\begin{array}{c}.669 \\
\mathrm{a}\end{array}$ & .448 & .439 & .43409 \\
\hline \multicolumn{4}{|c|}{ a. Predictors: (Constant), responsiveness } \\
\hline
\end{tabular}

As seen in table (3), the value of $\mathrm{R}$ square $=.448$ this indicates that $45 \%$ of variables are explained.

Table.4: ANOVA

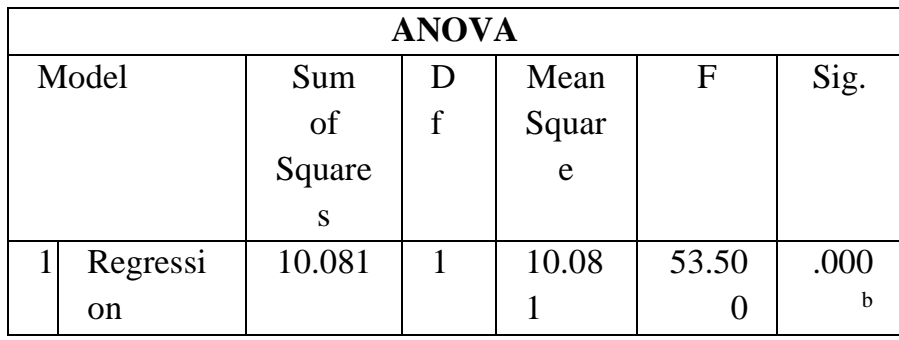

\begin{tabular}{|l|l|l|l|l|l|}
\hline Residual & 12.436 & 66 & .188 & & \\
\hline Total & 22.517 & 67 & & & \\
\hline
\end{tabular}

a. Dependent Variable: Customer satisfaction

b. Predictors: (Constant), responsiveness

As seen in table (4) the value of $F$ for responsiveness as independent variable and customer satisfaction as a dependent variable is $53.500>1$ which indicates there is a significant relationships between responsiveness as independent variable and customer satisfaction as dependent variable.

Table.5: Coefficients

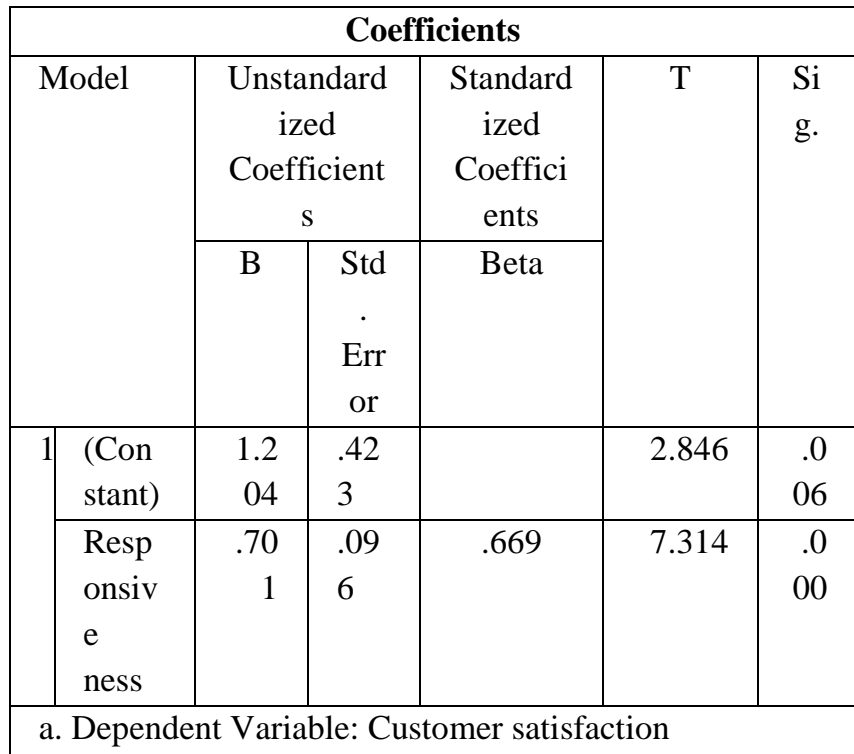

As seen in table (5) the value B for responsiveness= $.701>0.01$ this indicates that there is a positive relationship between responsiveness and customer satisfaction in call center accordingly the first research hypothesis supported.

Testing Second research hypothesis:

As seen in table (6) the correlation analysis between assurance as independent factor and customer satisfaction as dependent factor. The researcher found that the Pearson correlation for assurance $=.720^{* *}\left(.720^{* *}>0.01\right)$ which indicates that there is a positive correlation between assurance as independent factor and customer satisfaction as dependent factor.

As seen in table (7), the value of $\mathrm{R}$ square $=.511$ this indicates that $51 \%$ of variables are explained.

As seen in table (8) the value of $F$ for assurance as independent variable and customer satisfaction as a dependent variable is $70.910>1$ which indicates there is a significant relationships between assurance as independent variable and customer satisfaction as dependent variable. 


\begin{tabular}{|c|c|c|c|}
\hline \multicolumn{4}{|c|}{ Table.6: Correlation Analysis } \\
\hline \multicolumn{4}{|l|}{ Correlations } \\
\hline Items & $\begin{array}{l}\text { Pearson } \\
\text { Correlation }\end{array}$ & $\begin{array}{l}\text { Customer } \\
\text { satisfaction }\end{array}$ & Assurance \\
\hline \multirow[t]{3}{*}{$\begin{array}{l}\text { Responsive } \\
\text { ness }\end{array}$} & $\begin{array}{l}\text { Pearson } \\
\text { Correlation }\end{array}$ & $.720^{* *}$ & 1 \\
\hline & $\begin{array}{l}\text { Sig. } \\
\text { tailed) }\end{array}$ & .000 & \\
\hline & $\mathrm{N}$ & 68 & 68 \\
\hline \multirow[t]{3}{*}{$\begin{array}{l}\text { Customer } \\
\text { satisfaction }\end{array}$} & $\begin{array}{l}\text { Pearson } \\
\text { Correlation }\end{array}$ & 1 & $.720^{* *}$ \\
\hline & $\begin{array}{l}\text { Sig. } \\
\text { tailed) }\end{array}$ & & .000 \\
\hline & $\mathrm{N}$ & 68 & 68 \\
\hline
\end{tabular}

Table.7: Model Summary

\begin{tabular}{|c|c|c|c|c|}
\hline \multicolumn{4}{|c|}{ Model Summary } \\
\hline el
\end{tabular}

Table.8: ANOVA

\begin{tabular}{|c|c|c|c|c|c|c|}
\hline \multicolumn{7}{|c|}{ ANOVA } \\
\hline \multicolumn{2}{|c|}{ Model } & Sum of & Df & Mean & $\mathrm{F}$ & Sig. \\
\hline \multirow[t]{3}{*}{1} & Regression & 11.663 & 1 & 11.663 & 70.910 & $.000^{\mathrm{b}}$ \\
\hline & Residual & 10.855 & 66 & .164 & & \\
\hline & Total & 22.517 & 67 & & & \\
\hline
\end{tabular}

Table.9: Coefficients

\begin{tabular}{|c|c|c|c|c|c|}
\hline \multicolumn{6}{|l|}{ Coefficients } \\
\hline \multirow[t]{2}{*}{ Model } & \multicolumn{2}{|c|}{$\begin{array}{l}\text { Unstandardiz } \\
\text { ed } \\
\text { Coefficients }\end{array}$} & \multirow{2}{*}{$\begin{array}{l}\text { Standardiz } \\
\text { ed } \\
\text { Coefficient } \\
\text { s } \\
\text { Beta }\end{array}$} & \multirow[t]{2}{*}{$\mathrm{t}$} & \multirow[t]{2}{*}{$\begin{array}{c}\mathrm{S} \\
\text { ig. }\end{array}$} \\
\hline & B & $\begin{array}{l}\text { Std. } \\
\text { Error }\end{array}$ & & & \\
\hline $\begin{array}{l}\text { (Constant } \\
\text { ) }\end{array}$ & $\begin{array}{r}1 . \\
132\end{array}$ & $7^{.37}$ & & $\begin{array}{r}3 . \\
006\end{array}$ & 004 \\
\hline $\begin{array}{l}\text { Respon } \\
\text { sive ness }\end{array}$ & $27^{.7}$ & $6^{.08}$ & .720 & $\begin{array}{r}8 . \\
421\end{array}$ & 000 \\
\hline
\end{tabular}

As seen in table (9) the value $\mathrm{B}$ for assurance $=.727>0.01$ this indicates that there is a positive relationship between assurance and customer satisfaction in call center accordingly the second research hypothesis supported.

\section{CONCLUSION}

Researchers conclude that there is positive relationship between responsiveness and assurance with customer satisfaction. The researchers proposed to study theoretical foundations on customer satisfaction and service quality dimensions, SERVQUAL to investigative the impact of service quality dimensions on customer satisfaction to meet the research objective. The association between service quality and customer satisfaction will assist call center management to clarify what these service quality dimensions mean to the customers and to call center itself. This research tested the effect of service quality dimensions on customer satisfaction and found out that both dimensions (responsiveness and assurance) had positive impact on customer satisfaction. Consequently the findings of this study could be useful to call center managers with respect to how to deal with customers, to maintain and improve the call centers' main objective of revenue maximization and minimizing the cost.

\section{ACKNOWLEDGMENT}

Authors would like to thank Ishik University, Erbil, Northern Iraq for supporting current research.

\section{REFERENCES}

[1] Bhawan, M. D. (2014, March). The Indian Telecom Services Performance Indicators. Retrieved February 20, 2016, from Telecom Regulatory Authority of India: http://www.trai.gov.in/ WriteReadData/PIRReport/Documents/Indicator\%20 Reports\%20-\%20Mar-14.pdf

[2] Davis, G., Yoo, M., and Baker, W., 2003, "The small world of the American corporate elite, 1982-2001" Strategic Organization, Vol, 1 No. 3 pp. 301-326.

[3] Dietz J, Pugh SD and Wiley JW (2004) Service climate effects on customer attitudes: An examination of boundary conditions. Academy of Management Journal 47: 81-92.

[4] Eichfeld, A., Morse, T.D. and Scott, K.W. 2006. Using Call Centers to Boost Revenue, McKinsey Quarterly, May: 1-7.

[5] Eshghi, A., Roy, S., and Ganguli, S., 2008, "Service quality and customer satisfaction: An empirical investigation in Indian mobile Telecommunications services", Marketing Management Journal, Vol. 18, No. 2, p. 119-144.

[6] Homburg, C., Koschate, N., \& Hoyer, W. D. (2005). Do satisfied customers really pay more? A study of 
the relationship between customer satisfaction and willingness to pay.Journal of Marketing,69(2), 84-96.

[7] Kotler, P. and Keller, K. L. (2009) Marketing management (13th end). New Jersey: Pearson Education Inc, Upper Saddle River.

[8] Oliver RL (1997) Satisfaction: a behavioural perspective on the consumer (ed.). New York, NY: McGraw-Hill.

[9] Parasuraman, A., Zeithaml, V. A., \& Berry, L. L. (1985). A conceptual model of service quality and its implications for future research. Journal of Marketing, 49, 41-50.

[10]Zineldin, M. (2006). The royalty of loyalty: CRM, quality and retention. Journal of Consumer Marketing, 23(7), 430-437. 